\title{
Gender, race, and global capitalism at WORK-social changes, continuities and struggles
}

\author{
Kristina Binner · Fabienne Décieux · Johanna Grubner
}

(C) Österreichische Gesellschaft für Soziologie 2020

Currently interconnected upheavals and transformations are taking place. In the light of recent capitalist processes the interplay of gender, race, and class as central, structuring and constituting categories for the organization of societies is especially challenged. In the German-speaking scientific community, a broad field of research has established among questions of gender and work, also acknowledging the importance of race/ethnicity and class (e.g. Aulenbacher et al. 2007; Aulenbacher and Wetterer 2009; Wetterer 2002; Becker et al. 2020; Gruhlich and Seeliger 2019; Gruhlich et al. 2020; Gruhlich and Kutzner 2020; Artus and Rehder 2017; Hürtgen in: Atzmüller et al. 2015; Lenz et al. 2017). With increasing interest the question of intersectional inequalities as well as concrete socio-spatial and situational entanglements is been discussed in the sociology of work and gender studies (different perspectives, e.g. Hürtgen 2020; Lutz 2018; Sproll in this issue). Against this backdrop, the current special issue sheds some light on current debates and thereby wants to push the discourse forward. The aim of this volume is to present a mixture of articles, which take different sociological theories into account as well as several empirical fields and questions.

This special issue is based on selected contributions that have been presented and discussed in the context of the conference Gender, Race, and global Capitalism at WORK-Social changes, continuities and struggles, which took place in November

\footnotetext{
K. Binner $(\bowtie) \cdot$ J. Grubner

Institut für Soziologie, Johannes-Kepler-Universität Linz, Altenberger Straße 69, 4040 Linz, Austria

E-Mail: kristina.binner@jku.at

J. Grubner

E-Mail: johanna.grubner@jku.at

F. Décieux

Institut für Soziologie, Universität Wien, Rooseveltplatz 2, 1090 Wien, Austria

E-Mail: fabienne.decieux@univie.ac.at
} 
2018 at the Johannes Kepler University in Linz. The conference was organized by the Section for the sociology of work and the section for Feminist Theory and Gender Studies of the Austrian Sociological Association (ÖGS, Österreichische Gesellschaft für Soziologie). The assembled contributions show a high degree of originality and depth both on the theoretical and empirical level. They deal with socially and societally highly relevant areas and describe developments in work, gender, and power relations with contemporary diagnostic references. From a social theory perspective, the simultaneity of the non-simultaneity of relevant phenomena in the context of contemporary capitalist developments are illustrated in particular fields and different spatial as well as theoretical perspectives in the context of work are taken into account.

The special issue starts with a contribution by Martina Sproll who discusses questions of inequality in contemporary capitalism from a global perspective. In her paper she stresses the significance of inequality-or to put it more explicitly of intersectionality - for the dynamic of global production drawing on the theories of global value chains. Her paper Ungleichheit in globalen Wertschöpfungsketten: eine intersektionale Perspektive auf soziale Reproduktion shows the relevance of social inequality in transnational networks, recognizing the role of gender, by illuminating interdependence of paid and unpaid as well as formal and informal work in the productive and the reproductive sphere. Sproll argues, that "accumulation in global value chains is always based on the exploitation of different dimensions of inequality". With her theoretically informed perspective on global value chains and production networks, she gives a broad insight into the interplay of contemporary capitalism and intersectionality.

By highlighting the socio-spatial entanglement of intersectional categories in Germany, Ilse Lenz invites us to rethink the concept or at least the different categories used in intersectionality. In her paper Globaler flexibilisierter Kapitalismus und prozessuale Intersektionalität: Die Veränderungen nach Geschlecht und Migration in den Berufsrängen in Deutschland she uses data from the micro census to analyse the labor market and show the changes and continuities of the occupational positions of migrants between 1996 and 2011 in Germany. She argues, that intersectional inequalities are being reorganised and differentiated in new and complex ways.

Also focusing on migrant work-but on women in Spain-Johanna Neuhauser's contribution "Für Frauen gibt es immer Arbeit!" - Eine intersektionale Analyse migrantischer Arbeit in Spanien provides a differentiated analysis of exploitation and articulates the structural mechanisms by focusing on the subjective perceptions of social inequality. With her conceptual article, she shows "that an intersectional analysis of migrant labor can provide privileged access to fundamental social contradictions and reveal hidden power relations." Her qualitative approach and the sample of mainly Latin American migrants allow her to get deep insights in the consequences of crises on female migrant workers in Spain.

The article Die neue "heimliche Ressource der Sozialpolitik"? Soziales Engagement als geschlechterpolitisch ambivalenter Möglichkeitsraum im Community Kapitalismus by Tine Haubner sheds light on questions of intersectionality from a different perspective. The author examines the sphere of social reproduction and care 
from a socio-political perspective and focuses on unpaid social volunteer work in Germany, as a traditional field of feminist research (e.g., Beck-Gernsheim 1991; Notz 1987). Her contribution provides a closer look into the field and asks about its gendered structures. Haubner shows the ambivalences in social volunteer work as space of opportunity in terms of gender equality.

The last contribution also investigates a traditional field of female work. Isabel Klein takes a closer look at beauticians and their working conditions. In her article Von der Arbeit, wie eine Freundin zu sein: Beziehungsarbeit in prekären und feminisierten Dienstleistungsbeziehungen she interprets- the mainly self-employed-work of beauticians as emotional labor and suggests the term "relationship work" in order to adequately research the invisible boundary work hidden behind the actual service work-a common phenomenon in female dominated work fields (e.g., Hochschild 1983; Hochschild 2002; Koch and Buchanan 2013).

The special issue is rounded off with reviews on two recently published books that show the vivid debates about the restructuring of society and work under the influence of contemporary capitalism from two specific perspectives. Laura Grubner reviews the recently published book Gespannte Arbeits- und Geschlechterverhälnisse im Marktkapitalismus, edited by Becker et al. (2020). She locates the book as a critical contribution to the debate of capitalism at the interface of sociology of work and gender studies. With an informative and diverse collection, the book combines new research as well as analyses of current developments. From different perspectives the contributions deal with the "consequences of forced economization" on gender relations and thus emphasize the critique of interlocking power relations in market capitalism, Grubner states. Melanie Schinnerl reviews a recent publication of Atzmüller (2019). Schinnerl identifies his book Krisenbearbeitung durch Subjektivierung. Kritische Theorie der Veränderung des Staates im Kontext humankapitalkonzentrierter Sozialpolitik as an important contribution to debates on the transformation and reconfiguration processes of welfare state activities in the context of activation/workfare and social investment, which have led to "far-reaching, nationally varying polarization and fragmentation tendencies of welfare state activities, goals and apparatuses" (Atzmüller 2019, p. 43, trans. by eds.). Nevertheless, it is a matter of fundamental changes in the commodity of labor or its working capacity, which is increasingly being understood as human capital within the context of activation policy and social investment activities.

We want to thank all the persons who supported and contributed to the publication of this special issue: First of all, this affects the supporters of our conference: Brigitte Aulenbacher and the department for the Theory of Society and Social Analysis at the Johannes Kepler University, Linz; Claudia Globisch and the institute of Sociology at the University Innsbruck; Eduard Müller (JKU); the ÖGS (Österreichische Gesellschaft für Soziologie), the Sections for Sociology of Work and Feminist Theory and Gender Studies. Of course our thank concerns those, who were engaged directly in getting the volume done: Thanks to the anonymous reviewers. They have improved the quality of the papers conclusively. We also want to thank the authors. Without them, there would be no volume. The papers have definitely benefited from being proofread by Elisabeth Stadler. Finally, many thanks to the editorial team of the ÖZS, with special thanks to Martina Beham-Rabanser and the Springer-Verlag. 


\section{References}

Artus, Ingrid, and Britta Rehder. 2017. Industrielle Beziehungen und Gender. Einleitung zum Schwerpunktheft. Industrielle Beziehungen. Zeitschrift für Arbeit, Organisation und Management 24(2):131-134. https://doi.org/10.3224/indbez.v24i2.01.

Atzmüller, Roland. 2019. Krisenbearbeitung durch Subjektivierung. Kritische Theorie der Veränderung des Staates im Kontext humankapitalzentrierter Sozialpolitik. Münster: Westfälisches Dampfboot.

Atzmüller, Roland, Stefanie Hürtgen, and Manfred Krenn (eds.). 2015. Die zeitgemäße Arbeitskraft. Qualifiziert, aktiviert, polarisiert. Weinheim: Beltz Juventa.

Aulenbacher, Brigitte, and Angelika Wetterer (eds.). 2009. Arbeit. Perspektiven und Diagnosen der Geschlechterforschung. Münster: Westfälisches Dampfboot.

Aulenbacher, Brigitte, Maria Funder, Heike Jacobsen, and Susanne Völker (eds.). 2007. Arbeit und Geschlecht im Umbruch der modernen Gesellschaft. Forschung im Dialog. Wiesbaden: VS.

Beck-Gernsheim, Elisabeth. 1991. Frauen - die heimliche Ressource der Sozialpolitik. WSI-Mitteilungen 2:58-66.

Becker, Karina, Kristina Binner, and Fabienne Décieux (eds.). 2020. Gespannte Arbeits- und Geschlechterverhältnisse im Marktkapitalismus. Wiesbaden: Springer VS.

Gruhlich, Julia, and Edelgard Kutzner. 2020. Geschlecht, Arbeit, Organisation. GENDER - Zeitschrift für Geschlecht, Kultur und Gesellschaft 12(2-2020):7-10. https://doi.org/10.3224/gender.v12i2.01.

Gruhlich, Julia, and Martin Seeliger (eds.). 2019. Intersektionalität, Arbeit und Organisation. Weinheim: Juventa.

Gruhlich, Julia, Edelgard Kutzner, and Diana Lengersdorf. 2020. Geschlecht, Arbeit, Organisation. Aktuelle Entwicklungen in der Arbeitswelt. Schwerpunktheft der Zeitschrift Gender.

Hochschild, Arlie R. 1983. The managed heart. Commercialization of human feeling. Berkeley: University of California Press.

Hochschild, A.R. 2002. The sociology of emotion as a way of seeing. In Emotions in social life, ed. Gillian Bendelow, 5-15. London, New York: Routledge.

Hürtgen, Stefanie. 2020. Der transnationale soziale Raum der Lohnarbeit in feministischer Perspektive. Multi-skalare Kombinationen von Hegemonie und Despotie. In Gespannte Arbeits- und Geschlechterverhältnisse im Marktkapitalismus, ed. Karina Becker, Kristina Binner, and Fabienne Décieux. Wiesbaden: Springer VS.

Koch, Gertraud, and Stefanie E. Buchanan. 2013. Pathways to empathy. New studies on commodification, emotional labor, and time binds. Frankfurt a.M.: Campus.

Lenz, Ilse, Sabine Evertz, and Saida Ressel (eds.). 2017. Geschlecht im flexibilisierten Kapitalismus? Neue UnGleichheiten. Wiesbaden: Springer VS.

Lutz, Helma. 2018. Care migration: The connectivity between care chains, care circulation and transnational social inequality. Current Sociology 66(4):577-589. https://doi.org/10.1177/0011392118765 213.

Notz, Gisela. 1987. Arbeit ohne Geld und Ehre. Zur Gestaltung ehrenamtlicher sozialer Arbeit. Wiesbaden: VS.

Wetterer, Angelika. 2002. Arbeitsteilung und Geschlechterkonstruktion. Gender at Work in theoretischer und historischer Perspektive. Konstanz: VK Verlag.

Kristina Binner Dr. Kristina Binner arbeitet als wissenschaftliche Mitarbeiterin in der Abteilung für Gesellschaftstheorie und Sozialanalysen des Institutes für Soziologie der Johannes Kepler Universität in Linz. Ihre Arbeitsschwerpunkte umfassen: Arbeits- und Organisationssoziologie, Geschlechterforschung, Hochschul- und Wissenschaftsforschung, Migration und Gesellschaft. Ausgewählte Publikationen: Binner, Kristina, und Karin Scherschel (Hrsg.). 2020. Fluchtmigration und Gesellschaft. Von Nutzenkalkülen, Solidarität und Exklusion (Arbeitsgesellschaft im Wandel). Weinheim: Juventa. Becker, Karina; Kristina Binner und Fabienne Décieux. 2020. Gespannte Arbeits- und Geschlechterverhältnisse im Marktkapitalismus (Geschlecht und Gesellschaft, Nr. 72). Wiesbaden: Springer. 
Fabienne Décieux ist wissenschaftliche Mitarbeiterin am Institut für Soziologie der Universität Wien. Sie forscht und arbeitet im Bereich der kritischen Gesellschaftstheorie, Arbeitssoziologie, zu Fragen rund um Sozialpolitik, Geschlechterforschung und Care. Ihre letzten zwei Publikationen sind: Atzmüller, Roland; Brigitte Aulenbacher, Ulrich Brand, Fabienne Décieux, Karin Fischer und Birgit Sauer (Hrsg.). 2019. Capitalism in Transformation: Movements and Countermovements in the 21st Century. Cheltenham: Edward Elgar Publishing. Décieux, Fabienne. 2020. Sorgearbeit und zukünftige zeitgemäße Arbeitskraft im Gegenwartskapitalismus. In Gespannte Arbeits- und Geschlechterverhältnisse im Marktkapitalismus, Hrsg. Karina Becker, Kristina Binner, und Fabienne Décieux, 191-212 (Geschlecht und Gesellschaft, Nr. 72). Wiesbaden: Springer.

Johanna Grubner ist wissenschaftliche Mitarbeiterin in der Abteilung für Gesellschaftstheorie und Sozialanalysen des Institutes für Soziologie der Johannes Kepler Universität in Linz. Ihre Forschungsschwerpunkte liegen im Bereich der kritischen Gesellschaftsanalyse sowie Arbeitssoziologie und umfassen feministische Theorien und Geschlechterforschung, Wissenschafts- und Hochschulforschung mit Fokus auf universitäre Gleichstellung. Aktuelle Publikationen: Aulenbacher, Brigitte, und Johanna Grubner. 2020, i. E.: Work/labor, Perspectives from the sociology of work and industrial sociology on the transformation of paid work. In Soziologie-Sociology in the German-speaking World. Special Issue, Soziologische Revue 2020, eds. Betina Hollstein, Rainer Greshoff, Uwe Schimank, und Anja Weiß. Berlin: De Gruyter. Global Dialogue-Magazine of the International Sociological Association. Editors: Brigitte Aulenbacher, Klaus Dörre; Assistant Editor: Johanna Grubner, Christine Schickert. Nov. 2020, Vol. 10, Issue 3. 